\title{
Article
}

https://doi.org/10.11646/phytotaxa.405.4.1

\section{Neofavolus subpurpurascens comb. nov., with new records from the Neotropics}

\author{
MELISSA PALACIO ${ }^{1 *}$, ROSA MARA BORGES DA SILVEIRA ${ }^{2} \&$ GERARDO LUCIO ROBLEDO $^{3}$ \\ 1,2Universidade Federal do Rio Grande do Sul, Instituto de Biociências, Departamento de Botânica, Av. Bento Gonçalves, 9500, Prédio \\ 43.433, Campus do Vale, Agronomia, 91501-970, Porto Alegre, RS, Brazil \\ ${ }^{3}$ BioTecA3 - Centro de Biotecnología Aplicada al Agro y Alimentos, Facultad de Ciencias Agropecuarias - Univ. Nac. de Córdoba, Ing. \\ Agr. Félix Aldo Marrone 746 - Planta Baja, CC509 - CP 5000, Ciudad Universitaria. Fundación FungiCosmos, www.fungicosmos.org. \\ "E-mail: melissapalacio@gmail.com
}

\begin{abstract}
Polyporus subpurpurascens is a rare Neotropical species characterized by deep purplish pilear surface and radially elongated pores. This study analyzed Neotropical specimens from Argentina, Bolivia and Brazil by applying detailed morphological examination and phylogenetic analyses. We conclude that P. subpurpurascens is a species of Neofavolus, and N. subpurpurascens is proposed as a new combination. New records from Argentina and Bolivia, a detailed description, and photographs of the species are included.
\end{abstract}

\section{Introduction}

Favolus E.M. Fries (1828: 44) and Neofavolus Sotome \& T. Hatt. in Sotome et al. (2013: 249) are white rot polypore genera with similar annual flabelliform basidiomes that are laterally stipitate without black crust on the stipe surface. Microscopically, they are characterized by a dimitic hyphal system with skeletal-binding hyphae and hyaline thinwalled cylindrical basidiospores (Sotome et al. 2013). A glabrous pilear surface and a cutis pileipellis with agglutinated hyaline to brown generative hyphae differentiate Neofavolus from Favolus. In contrast, the pileipellis in Favolus is composed of non-agglutinated hyaline hyphae.

Originally, Neofavolus was exclusively described as having poroid basidiomes and being distributed in temperate areas. Neofavolus mikawae (Lloyd) Sotome \& T. Hatt. in Sotome et al. (2013: 251) and N. cremeoalbidus Sotome \& T. Hatt. in Sotome et al. (2013: 250) have angular pores and $N$. alveolaris (DC.) Sotome \& T. Hatt. in Sotome et al. (2013: 250) have radially elongated pores. However, N. suavissimus (Fr.) J.S. Seelan, Justo \& Hibbett in Seelan et al. (2015: 468), a subporoid lamellate species, was recently included in the genus Neofavolus (Seelan et al. 2015).

Polyporus subpurpurascens (Murrill) Ryvarden (1985: 181) is a rare species described from Jamaica (Murrill 1907), characterized by a deep purple pilear surface. Polyporus is a polyphyletic genus (Sotome et al. 2008, Krüger et al. 2006, Sotome et al. 2011, Dai et al. 2014, Seelan et al. 2015) and the phylogenetic relationships of P. subpurpurascens remain unknown. We aim to perform accurate morphological and molecular analyses of specimens identified as $P$. subpurpurascens from Argentina, Bolivia and Brazil in order to access their phylogenetic position.

\section{Material and Methods}

\section{Specimens}

Specimens of several herbaria (ICN, LIL and CORD) collected from Northwest Argentina, Bolivia and South Brazil were included in this study. Freehand cross sections of dried materials mounted in Melzer's reagent, $5 \% \mathrm{KOH}$ and/or $1 \%$ phloxine, lactophenol, cresyl blue and/or cotton blue - (CB) were observed under the microscope.

\section{DNA extraction, PCR amplification and sequencing}

DNA was extracted from the dried specimens using CTAB rapid plant genome extraction kit-DN14 (Aidlab Biotechnologies Co., Ltd., Beijing, China) and FH plant DNA kit II (Demeter Biotech Co., Ltd., Beijing, China), 
following the manufacturers protocols. Primer pairs ITS4/ITS5 (White et al. 1990) and LR0R/LR7 (Vilgalys \& Hester 1990) were used to amplify the nrITS and nrLSU regions, respectively, by a qualitative simplex polymerase chain reaction. The polymerase chain reaction (PCR) protocol for ITS was the following: initial denaturation at $95^{\circ} \mathrm{C}$ for 3 min, followed by 35 cycles of $94{ }^{\circ} \mathrm{C}$ for $40 \mathrm{~s}, 54{ }^{\circ} \mathrm{C}$ for $45 \mathrm{~s}$, and $72{ }^{\circ} \mathrm{C}$ for $1 \mathrm{~min}$, and final extension of $72{ }^{\circ} \mathrm{C}$ for 10 $\mathrm{min}$. The PCR procedure for $28 \mathrm{~S}$ was the following: initial denaturation at $94{ }^{\circ} \mathrm{C}$ for $1 \mathrm{~min}$, followed by 35 cycles of $94{ }^{\circ} \mathrm{C}$ for $30 \mathrm{~s}, 50^{\circ} \mathrm{C}$ for $1 \mathrm{~min}$, and $72{ }^{\circ} \mathrm{C}$ for $1.5 \mathrm{~min}$, and final extension of $72{ }^{\circ} \mathrm{C}$ for $10 \mathrm{~min}$. The PCR products were purified and sequenced with the same primers at Beijing Genomics Institute in China.

\section{Phylogenetic analyses}

Sequences were manually edited using Geneious v. 11.1.4 (http://www.geneious.com, Kearse et al. 2012). The generated sequences, including related sequences downloaded from GenBank (Table 1), were aligned using Mafft v.7 (Katoh \& Standley 2013). Besides, the Q-INS-I strategy was adopted for for nrITS and G-INS-i, for nrLSU. The alignments were manually examined and adjusted with MEGA 6 (Tamura et al. 2013). We used a combined dataset with nrITS and nrLSU. The dataset was divided into four data partitions: ITS1, 5.8S, ITS2 and LSU. The best-fit model of nucleotide evolution for each partition was selected according to the Akaike Information Criterion and using jModelTest2 v.1.6 (Darriba et al. 2012; Guindon \& Gascuel, 2003) as available in CIPRES Science Gateway 3.1 (Miller et al. 2010). The final alignments were submitted to TreeBASE (submission ID: 22972). Both Bayesian Inference (BI) and Maximum Likelihood (ML) phylogenetic analyses were carried out. BI was conducted using MrBayes 3.2.6 (as available in CIPRES Science Gateway 3.1) and implementing two independent runs, each with four chains and starting from random trees. The runs produced 20,000,000 generations and trees were sampled every 1000th generation. Twenty five percent of the sampled trees were discarded as burn-in, while the rest were used for calculating a $50 \%$ majority consensus tree and Bayesian Posterior Probabilities (BPP). ML trees were obtained using RAxML v.8.1.4 (Stamatakis 2014) from CIPRES Science Gateway. The analysis first involved 100 ML searches, each one starting from a randomized stepwise-addition parsimony tree in a GTRGAMMA model with no proportion of invariant sites and all the other parameters estimated by the software. We provided a partition file to force RAxML software to search for a separate evolution model in each dataset. Bootstrap support values (BS) were obtained with multi-parametric bootstrapping replicates under the same model, allowing the program halts bootstrapping automatically by the autoMRE option. A node was considered to be strongly supported if it showed a BPP 0.95 and/or BS $90 \%$, while moderate support was considered when BPP $<0.95$ and/or BS $<90 \%$. Based on previous studies, Trametes conchifer (Schwein.) Pilát was used as outgroup (Zhou \& Cui 2018).

TABLE 1. List of species, specimen-voucher information, geographic origin, and GenBank accession numbers of sequences used in the phylogenetic analyses in this study.

\begin{tabular}{llllll}
\hline \multirow{2}{*}{ Species } & Voucher & Origin & Genbank accession numbers & References \\
\hline Datronia mollis & RLG6304sp & USA & JN165002 & JN164791 & Justo \& Hibbett (2011) \\
Favolus acervatus & Cui11053 & China & KU189774 & KU189805 & Zhou et al. (2016) \\
Favolus acervatus & Dai10749b & China & KX548953 & KX548979 & Zhou \& Cui (2018) \\
Favolus brasiliensis & TENN10242 & Costa Rica & AB735976 & AB368097 & Sotome et al. (2013) \\
Favolus brasiliensis & INPA241452 & Brazil & AB735977 & AB735953 & Sotome et al. (2013) \\
Favolus emerici & Cui10926 & China & KU189776 & KU189807 & Zhou et al. (2016) \\
Favolus emerici & Yuan4410 & China & KX548954 & KX548980 & Zhou \& Cui (2018) \\
Favolus niveus & Cui11129 & China & KX548955 & KX548981 & Zhou \& Cui (2018) \\
Favolus philippinensis & Cui10941 & China & KX548976 & KX548998 & Zhou \& Cui (2018) \\
Favolus philippinensis & Dai7959 & China & KX548977 & KX548999 & Zhou et al. (2016) \\
Favolus niveus & Dai13276 & China & KX548956 & KX548982 & Zhou \& Cui (2018) \\
Favolus pseudobetulinus & TRTC51022 & Canada & AB587629 & AB587620 & Sotome et al. (2011) \\
Favolus pseudobetulinus & TFMF27567 & Japan & AB587644 & AB587639 & Sotome et al. (2011) \\
Favolus pseudoemerici & Cui11079 & China & KX548958 & KX548984 & Zhou \& Cui (2018) \\
Favolus pseudoemerici & Cui13757T & China & KX548959 & KX548985 & Zhou \& Cui (2018) \\
Favolus roseus & PEN33 & Malaysia & AB735975 & AB368099 & Sotome et al. (2008) \\
\hline
\end{tabular}

......continued on the next page 
TABLE 1. (Continued)

\begin{tabular}{|c|c|c|c|c|c|}
\hline \multirow{2}{*}{ Species } & \multirow{2}{*}{ Voucher } & \multirow{2}{*}{ Origin } & \multicolumn{2}{|c|}{ Genbank accession numbers } & \multirow{2}{*}{ References } \\
\hline & & & nrITS & nrLSU & \\
\hline Favolus spatulatus & Dai13615 & China & KU189775 & KU189806 & Zhou et al. (2016) \\
\hline Favolus spatulatus & Cui8290 & China & KX548969 & KX548991 & Zhou et al. (2016) \\
\hline Favolus subtropicus & Cui4292 & China & KX548970 & KX548992 & Zhou \& Cui (2018) \\
\hline Favolus subtropicus & Li1938 & China & KX548971 & KX548993 & Zhou \& Cui (2018) \\
\hline Favolus sp. & MEL2382969 & Australia & KP012829 & KP012829 & GenBank \\
\hline Lentinus tigrinus & LE214778 & Russia & KM411459 & KM411475 & Zmitrovich \& Kovalenko (2016) \\
\hline Lentinus badius & DED07668 & Thailand & KP283480 & KP283518 & Seelan et al. (2015) \\
\hline Neofavolus alveolaris & Dai11290 & China & KU189768 & KU189799 & Zhou et al. (2016) \\
\hline Neofavolus alveolaris & Cui9900 & China & KX548974 & KX548996 & Zhou \& Cui (2018) \\
\hline Neofavolus cremeoalbidus & TUMH50006 & Japan & AB735979 & AB735956 & Sotome et al. (2013) \\
\hline Neofavolus cremeoalbidus & TUMH50008 & Japan & AB735981 & AB735958 & Sotome et al. (2013) \\
\hline Neofavolus cremeoalbidus & TUMH50009 & Japan & AB735980 & AB735957 & Sotome et al. (2013) \\
\hline Neofavolus mikawae & Cui11152 & China & KU189773 & KU189804 & Zhou et al. (2016) \\
\hline Neofavolus mikawae & Dai12361 & China & KX548975 & KX548997 & Zhou \& Cui (2018) \\
\hline Neofavolus suavissimus & DSH2011 & USA & KP283496 & KP283525 & Seelan et al. (2015) \\
\hline Neofavolus suavissimus & LE202237 & USA & KM411460 & KM411476 & Zmitrovich \& Kovalenko (2016) \\
\hline Neofavolus subpurpurascens & CG6241 & Brazil & MH544274 & MH544276 & This study \\
\hline Neofavolus subpurpurascens & CG6242 & Brazil & MH544275 & MH544277 & This study \\
\hline Neofavolus subpurpurascens & Robledo383 & Argentina & - & MH544278 & This study \\
\hline Neofavolus subpurpurascens & Robledo390 & Argentina & - & MH544280 & This study \\
\hline Neofavolus sp. & SV10 & USA & KP283507 & KP283526 & Seelan et al. (2015) \\
\hline Neofavolus sp. & M672 & USA & KP283506 & KP283524 & Seelan et al. (2015) \\
\hline Polyporus arcularius & Cui10998 & China & KX548973 & KX548995 & Zhou et al. (2016) \\
\hline Polyporus brumalis & Cuil 10750 & China & KU189765 & KU189796 & Zhou et al. (2016) \\
\hline Polyporus tuberaster & Dai12462 & China & KU507580 & KU507582 & Zhou et al. (2016) \\
\hline Trametes conchifer & FP106793sp & USA & JN164924 & JN164797 & Justo \& Hibbett (2011) \\
\hline
\end{tabular}

\section{Results}

Phylogenetic analyses

The dataset contains 44 sequences and 2060 characters, including gaps. In total, 397 of them are parsimony informative; 1536, constant; and 474, variable. Additionally, TIM3 $+\mathrm{I}+\mathrm{G}, \mathrm{TPM} 2+\mathrm{I}, \mathrm{HKY}+\mathrm{G}$, and GTR $+\mathrm{I}+\mathrm{G}$ were the evolutionary models selected for ITS1, 5.8S, ITS2 and LSU, respectively. The topology of the BI and ML analyses did not reveal any inconsistency in the supported clades, as is shown in the BI tree (Fig 1).

The phylogenetic analyses retrieved Neofavolus and Favolus as strongly-supported clades (BPP=1, BS =94, and $\mathrm{BPP}=0.99, \mathrm{BS}=93$, respectively). Furthermore, six linages in the Neofavolus clade were also retrieved. Four of those lineages contained specimens of $N$. alveolaris $(\mathrm{BPP}=0.99, \mathrm{BS}=98), N$. cremealbidus $(\mathrm{BPP}=1, \mathrm{BS}=100)$, $N$. mikawai $(\mathrm{BPP}=1, \mathrm{BS}=100)$, and $N$. suavissimus $(\mathrm{BPP}=1, \mathrm{BS}=100)$. Besides, there was a lineage composed of American specimens of a not-yet-described species of Neofavolus (BPP=1, BS =96) that has already been detected (Seelan et al. 2015). Finally, a strongly-supported lineage $(\mathrm{BPP}=1, \mathrm{BS}=100)$ composed of the six specimens collected in Argentina and Brazil was identified as $P$. subpurpurascens. 


\section{Taxonomy}

Both phylogenetic and morphological analyses revealed that the specimens previously identified as $P$. subpurpurascens belong to the Neofavolus clade. As a result, we propose the following new combination:

Neofavolus subpurpurascens (Murril) Palacio \& Robledo comb. nov.

MycoBank MB 826917

Basionym: Hexagonia subpurpurascens Murrill, North American Flora 9(1): 51 (1907).

Synonyms: Polyporus subpurpurascens (Murrill) Ryvarden, Mycotaxon 23: 181 (1985); Favolus subpurpurascens (Murrill) Sacc. \& Trotter, Syll. fung. (Abellini) 21: 357 (1912).

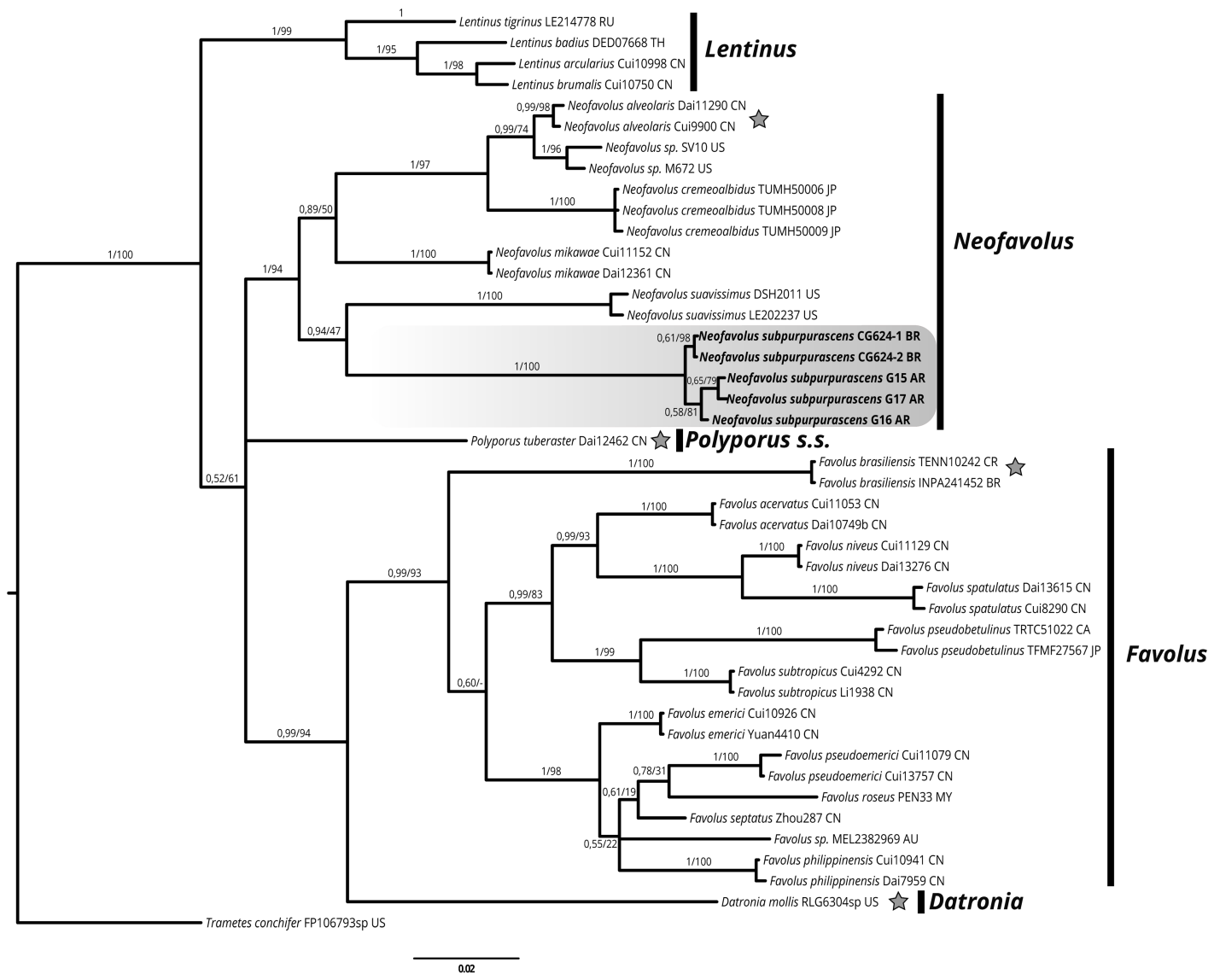

FIGURE 1. Phylogenetic relationships of Neofavolus and Favolus species inferred from nrITS and nrLSU sequences. Topology from Bayesian Inference analysis is presented. Bayesian posterior probabilities (before the slash markers) and Bootstrap support values (after the slash markers) are indicated. Red stars indicate type species of the genus.

Description:-Basidiome annual, fragile, centrally to laterally stipitate, solitary or clustered in small groups (2-3 basidiomes); pileus circular to reniform, centrally depressed, up to $2 \mathrm{~cm}$ diam., $0.1 \mathrm{~cm}$ thick, glabrous, azonate, light purplish, slightly tessullate when living, purplish ochraceous and tessellate when dry; stipe up to $2 \mathrm{~cm}$ long., 0.3 diam., light yellowish brown to purplish, with reddish dyes, more purplish and thicker towards the base, with a whitish attachment disc, smooth to longitudinally rugose when dry; margin acute, incurvated when dry; context thin $(0.2 \mathrm{~mm}$ thick) to absent. Pore surface light brown yellowish, pores $1-2 / \mathrm{mm}$, angular, hexagonal, radially elongated, decurrent, with hyphal pegs. Hyphal system dimitic: generative hyphae clamped, hyaline, thin walled, 3-6 $\mu \mathrm{m}$ diam., skeletobinding hyphae arboriform, hyaline to yellowish, thick walled, with a wide lumen 3-6 um diam. (in the principal stalk) or 2-3 $\mu \mathrm{m}$ diam. (in the branches), IKI-. Hyphal pegs 23-26 $\mu \mathrm{m}$ diam., composed of generative hyphae. Pileipellis present as a cutis composed of light brown, parallel, agglutinated, thick-walled generative hyphae, distinct from the contextual hyphae, which are hyaline, interwoven and non-agglutinated (Fig. 2). Basidia 18-22 × 6-8 $\mu \mathrm{m}$, 4-sterigmate, clavate. Basidiospores 9-12 $\times 2,5-4 \mu \mathrm{m}, \mathrm{Q}=3.2, \mathrm{n}=100 / 5$, narrowly cylindrical, with a slightly supraapicular depression, smooth, thin walled, hyaline, guttulate, IKI-. 
Geographical distribution:-Neofavolus subpurpurascens is a rare species, described from Jamaica and also recorded in Brazil (Coelho \& Silveira 2014). This is the first record from Argentina and Bolivia.

Remarks:-Neofavolus subpurpurascens is a species recognized by its purplish basidiomes, compared to other Neofavolus taxa, which are white to cream or brownish (Sotome et al. 2013; Seelan et al. 2015). The specimens under study match the macro and microscopical descriptions based on the type collection provided by Ryvarden (1985) and (Coelho \& Silveira 2014). Also we examined type material through NY virtual herbarium. Additionally, we found that the pilear surface is a cutis composed of light brown, parallel, agglutinated, thick-walled generative hyphae (Fig. 2c). Specimens:-ARGENTINA. Jujuy: Ledesma, Parque Nacional Calilegua, Mesada de las Colmenas, La Cascada trail, on dead twig, $1170 \mathrm{~m}, 23^{\circ} 42^{\prime} 1.5^{\prime} \mathrm{S}, 4^{\circ} 51^{\prime} 56.8^{\prime} \mathrm{W}, 6$ March 2005, Robledo 383 (CORD); Robledo 385 (CORD); Robledo 390 (CORD);-—BOLIVIA. La Paz: Nor Yungas, Rio Yariza, 23 February 1956, Singer B1346 (LIL);BRAZIL. Rio Grande do Sul: Santa Maria, Seminários São José, 23 March 2007, Coelho \& Cortez 624-1 (ICN); Coelho \& Cortez 624-2 (ICN).
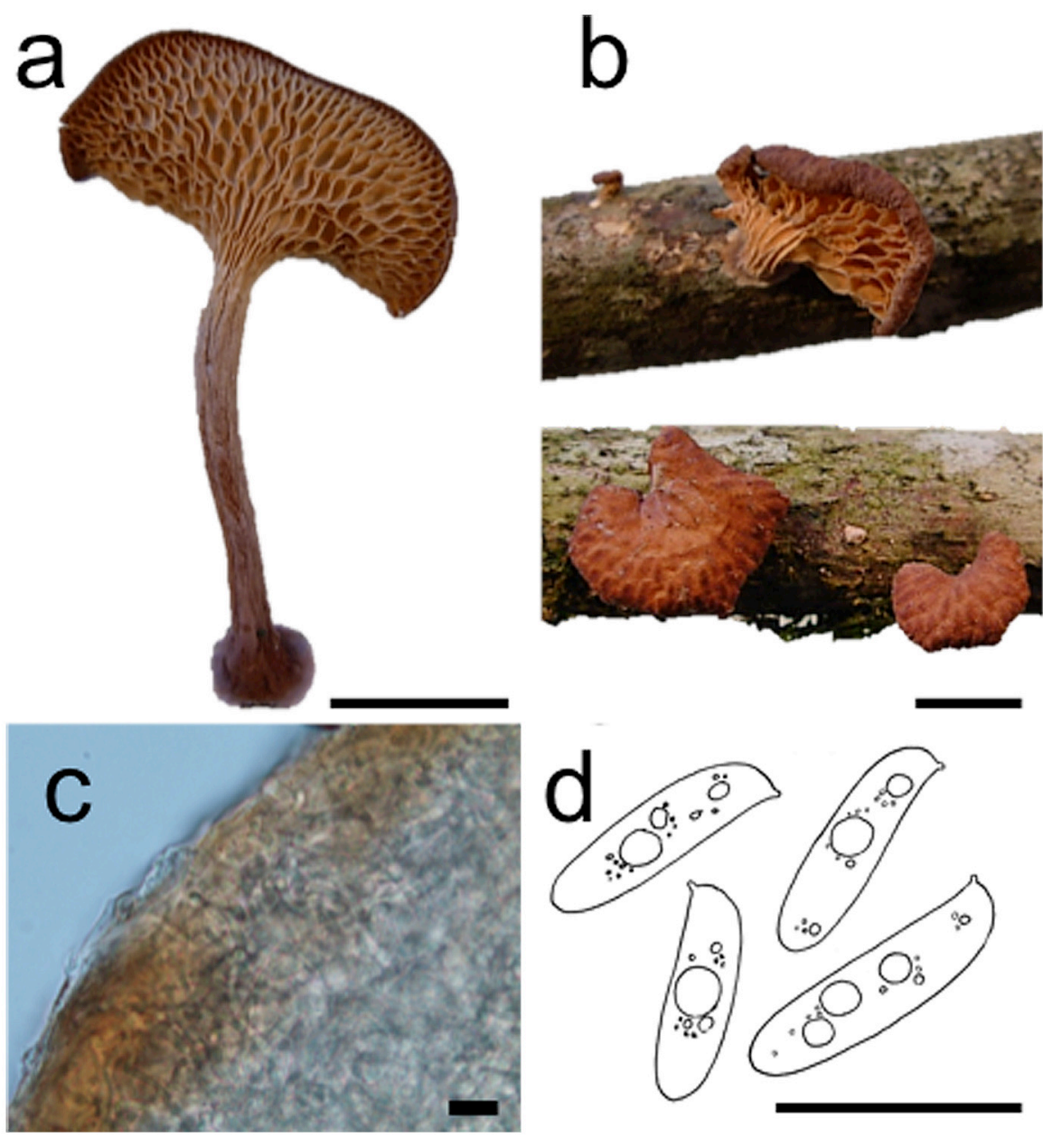

FIGURE 2. Morphological characteristics of $N$. subpurpurascens. a. pore surface detail. (Robledo383). b. pilear surface detail (Robledo390). c. pileipellis detail (CG624-1), cutis composed of light brown, parallel, agglutinated, thick-walled generative hyphae. d basidiospores (CG624-1). Scale bar: $\mathbf{a}, \mathbf{b}=1 \mathrm{~cm} ; \mathbf{c}, \mathbf{d}=10 \mu \mathrm{m}$.

\section{Discussion}

Neofavolus subpurpurascens is the only neotropical species of Neofavolus and a rare species that has been collected few times in South America. Other Neofavolus species have been found in temperate regions (Sotome et al. 2013) but not in the tropics. Specifically, Neofavolus alveolaris and N. suavissimus are known in the Northern Hemisphere (North America, Europe and Asia), N. mikawae was recorded in China and Japan, and N. cremeoalbidus is restricted to temperate areas in Japan (Sotome et al. 2013). 
Previously, N. subpurpurascens was mentioned as a member of the morphological group of Favolus (Ryvarden \& Iturriaga 2003, Drechsler-Santos et al. 2008) and also suggested as a species of Favolus (Sotome et al. 2013, Coelho \& Silveira 2014). However, none of those previous studies considered the pilear surface or the phylogenetic position of these species. In this study, we discovered that the pilear surface of $N$. subpurpurascens is a cutis composed of hyphae distinct from the contextual hyphae, as in other Neofavolus spp. (Sotome et al. 2013).

Therefore, the pilear surface is a useful and consistent feature to recognize Neofavolus species. Furthermore, the morphology of this surface has been highlighted as a strong feature in the classification of some polypore groups (CostaRezende 2016, Torres-Torres \& Guzmán-Dávalos 2012). However, this surface in Polyporus s.l is scarcely described. Neofavolus is the single genus in the Polyporus s.l. genera whose pilear surface has been accurately examined and compared. Considering the complexity of Polyporus s.l. species, pilear surface morphology is a recommended feature to validate and compare genera and species.

Since Polyporus s.l. is a polyphyletic and morphologically heterogeneous group, accurate morphological examination (e.g. Sotome et al. 2013, Palacio et al. 2017) may support the identification of morphological patterns.

\section{Acknowledgments}

Authors thank Prof. Yu-Cheng Dai, Xiao-Hong Ji, and Yuan Yuan for their assistance and support at the Institute of Microbiology (Beijing Forestry University, China) and the herbaria mentioned above for lending the reference material. Melissa Palacio gratefully acknowledges a PhD scholarship provided by Coordenacão de Aperfeiçoamento de Pessoal de Nivel Superior (CAPES), and Gerardo Robledo thanks Consejo Nacional de Investigaciones Científicas $y$ Técnicas (CONICET) and Universidad Nacional de Córdoba for the facilities that were used to carry out this work. Authors thank to the reviewers for their valuable comments and suggestions to improve the paper.

\section{References}

Coelho, G. \& Silveira, R.M.B. (2014) Taxonomy of Polyporus sensu lato and related genera (Basidiomycota) from Santa Maria, southern Brazil. Ciência e Natura 36 (II): 688-710.

https://doi.org/10.5902/2179460X14939

Costa-Rezende, D.H., Gugliotta, A.M., Goes-Neto, A., Reck, M.A., Robledo, G.L. \& Drechsler-Santos, E.R. (2016) Amauroderma calcitum sp. nov. and notes on taxonomy and distribution of Amauroderma species (Ganodermataceae). Phytotaxa 244 (2): 101-124. https://doi.org/10.11646/phytotaxa.244.2.1

Dai, Y.C., Xue, H.J., Vlasák, J., Rajchenberg, M., Wang, B. \& Zhou, L.W. (2014) Phylogeny and global diversity of Polyporus group Melanopus (Polyporales, Basidiomycota). Fungal Diversity 64 (1): 133-144. https://doi.org/10.1007/s13225-013-0248-3

Darriba, D., Taboada, G.L., Doallo, R. \& Posada, D. (2012) jModelTest 2: more models, new heuristics and parallel computing. Nature Methods 9 (8): 772. https://doi.org/10.1038/nmeth.2109

Drechsler-Santos, E.R., Ryvarden, L., Wartchow, F. \& Cavalcanti, M.A.Q. (2008) Polyporus elongoporus (Aphyllophorales, Poriaceae) sp. nov. Synopsis Fungorum 25: 38-43.

Guindon, S. \& Gascuel, O. (2003) A simple, fast and accurate method to estimate large phylogenies by maximum-likelihood. Systematic Biology 52: 696-704.

https://doi.org/10.1080/10635150390235520

Fries, E.M. (1828) Elenchus Fungorum 1: 1-238.

Justo, A. \& Hibbett, D.S. (2011) Phylogenetic classification of Trametes (Basidiomycota, Polyporales) based on a five-marker dataset. Taxon 60 (6): 1567-1583. https://doi.org/10.1002/tax.606003

Katoh, K. \& Standley, D.M. (2013) MAFFT multiple sequence alignment software version 7: improvements in performance and usability. Molecular Biology and Evolution 30: 772-780. https://doi.org/10.1093/molbev/mst010

Kearse, M., Moir, R., Wilson, A., Stones-Havas, S., Cheung, M., Sturrock, S., Buxton, S., Cooper, A., Markowitz, S., Duran, C., Thierer, T., Ashton, B., Mentjies, P. \& Drummond, A. (2012) Geneious Basic: an integrated and extendable desktop software platform for the organization and analysis of sequence data. Bioinformatics 28 (12): 1647-1649.

https://doi.org/10.1093/bioinformatics/bts199 
Krüger, D., Petersen, R.H. \& Hughes, K.W. (2006) Molecular phylogenies and mating study data in Polyporus with special emphasis on group “Melanopus”(Basidiomycota). Mycological Progress 5 (4): 185-206.

https://doi.org/10.1007/s11557-006-0512-y

Miller, M.A., Pfeiffer, W. \& Schwartz, T. (2010) Creating the CIPRES Science Gateway for inference of large phylogenetic trees. In: Proceedings of the Gateway Computing Environments Workshop (GCE). 14 Nov. 2010, New Orleans, LA, pp. 1-8. https://doi.org/10.1109/GCE.2010.5676129

Murrill, W.A. (1907) (Agaricales) Polyporaceae. North American Flora 9: 1-131.

Palacio, M., Robledo, G.L., Reck, M.A., Grassi, E., Góes-Neto, A. \& Drechsler-Santos, E.R. (2017) Decrypting the Polyporus dictyopus complex: Recovery of Atroporus Ryvarden and segregation of Neodictyopus gen. nov. (Polyporales, Basidiomyocta). PLoS ONE 12 (10): e0186183.

https://doi.org/10.1371/journal.pone.0186183

Ryvarden, L. (1985) Type studies in the Polyporaceae 17. Species described by W.A. Murrill. Mycotaxon 23: 169-198.

Ryvarden, L. \& Iturriaga, T. (2003) Studies in neotropical polypores 10. New polypores from Venezuela. Mycologia 95 (6): $1066-1077$. https://doi.org/10.1080/15572536.2004.11833021

Seelan, J.S.S., Justo, A., Nagy, L.G., Grand, E.A., Redhead, S.A. \& Hibbett, D. (2015) Phylogenetic relationships and morphological evolution in Lentinus, Polyporellus and Neofavolus, emphasizing southeastern Asian taxa. Mycologia 107 (3): $460-474$. https://doi.org/10.3852/14-084

Sotome, K., Hattori, T., Ota, Y., To-Anun, C., Salleh, B. \& Kakishima, M. (2008) Phylogenetic relationships of Polyporus and morphologically allied genera. Mycologia 100 (4): 603-615. https://doi.org/10.3852/07-191R

Sotome, K., Hattori, T. \& Ota, Y. (2011) Taxonomic study on a threatened polypore, Polyporus pseudobetulinus, and a morphologically similar species, P. subvarius. Mycoscience 52 (5): 319-326. https://doi.org/10.1007/S10267-011-0111-X

Sotome, K., Akagi, Y., Lee, S.S., Ishikawa, N.K. \& Hattori, T. (2013) Taxonomic study of Favolus and Neofavolus gen. nov. segregated from Polyporus (Basidiomycota, Polyporales). Fungal Diversity 58: 245-266. https://doi.org/10.1007/s13225-012-0213-6

Stamatakis, A. (2014) RAxML Version 8: A tool for Phylogenetic Analysis and Post-Analysis of Large Phylogenies. Bioinformatics 30 (9): 1312-1313. https://doi.org/10.1093/bioinformatics/btu033

Thiers, B. (2018) Index Herbariorum: a global directory of public herbaria and associated staff. New York Garden's Virtual Herbarium. Available from: http://sweetgum.nybg.org/ih/ (accessed 24 May 2018)

Tamura, K., Stecher, G., Peterson, D., Filipski, A. \& Kumar, S. (2013) MEGA6: Molecular Evolutionary Genetics Analysis Version 6.0. Molecular Biology and Evolution 30: 2725-2729. https://doi.org/10.1093/molbev/mst197

Torres-Torres, M.G. \& Guzmán-Dávalos, L. (2012) The morphology of Ganoderma species with a laccate surface. Mycotaxon 119: 201-216. https://doi.org/10.5248/119.201

Vilgalys, R. \& Hester, M. (1990) Rapid genetic identification and mapping of enzymatically amplified ribosomal DNA from several species of Cryptococcus. Journal of Bacteriology 172: 4238-4246. https://doi.org/10.1128/jb.172.8.4238-4246.1990

White, T.J., Bruns, T.D., Lee, S. \& Taylor, J.W. (1990) Amplification and direct sequencing of fungal ribosomal RNA genes for phylogenetics. In: Innis, M.A., Gelfand, D.H., Sninsky, J. \& White, T.J. (Eds.) PCR protocols: a guide to methods and applications. Academic Press, San Diego, pp. 315-322. https://doi.org/10.1016/B978-0-12-372180-8.50042-1

Zmitrovich, I.V. \& Kovalenko, A.E. (2016) Lentinoid and Polyporoid fungi, two generic conglomerates containing important medicinal mushrooms in molecular perspective. International Journal of Medicinal Mushrooms 18 (1): 23-38. https://doi.org/10.1615/IntJMedMushrooms.v18.i1.40

Zhou, J.L., Zhu, L., Chen, H. \& Cui, B.K. (2016) Taxonomy and phylogeny of Polyporus group Melanopus (Polyporales, Basidiomycota) from China. PLoS One 11 (8): e0159495. https://doi.org/10.1371/journal.pone.0159495

Zhou, J.L. \& Cui, B.K. (2018) Phylogeny and taxonomy of Favolus (Basidiomycota). Mycologia 109 (5): 766-779. https://doi.org/10.1080/00275514.2017.1409023 